\title{
History and the Quest for Unity in Nigeria
}

\author{
Ojong Echum Tangban
}

\begin{abstract}
This paper examines the role of history in the search for unity in Nigeria. It notes that since the amalgamation of the Northern and Southern Protectorates of Nigeria in 1914, the polity has been battling forces of disunity including leadership bankruptcy, ethno-religious crises and the minority question. In order to address the challenge of disunity, successive governments of the country have put in place pro-unity measures such as national policy on education that would engender unity, National Youth Service Corps scheme, physical infrastructure, mass mobilization and ethnic balancing in the country's public service. The paper observes that the near exclusion of History from the primary and secondary school systems curricula is a minus for the national policy on education. Finally, the paper concludes that History holds the key to understanding the numerous challenges facing the country and recourse to the discipline would in no small way foster unity in the country.
\end{abstract}

Index Terms-History, leadership, quest, unity.

\section{INTRODUCTION}

Nigeria is a deeply diversified state. It is made up of about 250 ethnic groups. Apart from diversity in ethnicity, the country is also divided along religious lines. The northern part is principally a Muslim area, while the southern segment is predominantly a Christian segment. However, in both segments, there are pockets of adherents of traditional religion.

What we know today as Nigeria was largely a colonial creation. Prior to the advent of colonialism, the area known today as Nigeria was peopled by different ethnic nationalities. Each of these nationalities evolved socio-political systems consistent with their needs and environment. Through such systems, the various groups were not only able to maintain law and order, but also maintained symbolic coherence between the mini-state and society in a mutually reinforcing way. The colonial interlude, however, disrupted the ongoing process of state building. Not only did the colonial authorities bring together those disparate groups and systems to create Nigeria in a manner that disregarded the existing disparities in cultural values and preferences, but also failed to make nation-building part of the foundation of the forceful process of state-building. A case in point is the fact that the amalgamation of 1914, despite all pretence to the contrary, failed to achieve unity by the British colonial authorities. Despite the amalgamation, the Southern and Northern Protectorates "continued to develop along different lines politically, socially and economically" [1] with mutual suspicion into the bargain. Nigeria became a sovereign state in 1960 with these contradictions intact. Indeed, far from

Manuscript received July 29, 2013; revised October 10, 2013.

Ojong Echum Tangban is with the Nigerian Defence Academy, kaduna, Nigeria (e-mail: ojongechumtangban@yahoo.com). waning, the contradictions deepened in the post-independence era with dire consequences for the unity of the country.

\section{Challenges to Unity IN Nigeria}

In this segment, we discuss the forces of disunity that have been afflicting the country since independence. They include leadership bankruptcy, ethno-religious crises, ethnic militia and the minority question. We begin with leadership bankruptcy.

\section{LEADERSHIP BANKRUPTCY}

The contradictions of the colonial era earlier noted not only persisted in the independence era, but also new dimensions of centrifugal forces erupted during the period. It is always convenient to continue to hold colonial legacies accountable for the deepening crisis of sustainable governance, democracy and development, and above all lack of unity in the country. At independence, Nigeria had a chance to address the contradictions inherited from the colonial experience, but it failed largely because of leadership bankruptcy. As Claude Ake (of blessed memory) has pointed out, the country's leaders at independence had every opportunity to undo the legacies of colonialism that were antithetical to sustainable democracy, development and unity but squandered them because of their perception of the state as an arena for serving their selfish interests. [2]

It should be noted that the fortunes of any state are tied up to the quality of its leadership. When a patriotic person is on the throne, good things including unity happen. History is replete with examples of how the fortunes of some nations have changed due to the vision of their leaders. George Washington of the United States of America; Winston Churchill of Britain; Mahatir Mohammed of Malaysia and Lee Kuan Yew of Singapore are good examples of leaders who transformed their respective countries politically and economically.

\section{ETHNO-RELIGIOUS CRISIS}

Apart from leadership bankruptcy, there is also the challenge of ethno-religious crisis which have plagued the country for quite a while. Ethno-religious divisions in themselves should not be a serious threat to the unity of any country. However, in Nigeria, they are manipulated by the political elite for selfish political and economic interests. The first manifestation of the manipulation of ethno-religious differences was the Nigerian Civil War which broke out in July 1967 and lasted till January 1970. Since then, Nigeria has been grappling with ethno-religious criseswhich are 
arguably the handiwork of the political class. Since 1980, no less than 16 ethno-religious crises with great potential to tear the country apart have occurred. [3] All too often, the perpetrators are not punished and this culture of impunity tends to encourage potential trouble makers to take the law into their hands at the slightest opportunity. Also, the victims of these crises are hardly compensated. They, therefore, develop a sense of alienation both from the perpetrators and government with negative impact on national unity.

\section{ETHNIC MiLITIAS}

A third challenge to the country's unity is ethnic militias, a novel phenomenon and a creation of the political class in pursuit of their selfish political and economic interests. [4] Such militias include, among others, Oodua People Congress (OPC), the Movement for the Actualisation of the Sovereign State of Biafra (MASSOB), and the Arewa People Congress (APC). These groups parade themselves as the military arms of the various ethnic groups in Nigeria. As a result, their activities have escalated inter-group tensions with negative impact on national unity.

\section{ThE MinORITY QUESTION IN NigERIA}

The minority problem pre-dates independence. The emergence of regionalism in the country saw the creation of three regions namely, North, East and West with each dominated by the three major ethnic groups, Hausa/Fulani in the North, Igbo in the East and Yoruba in the West. The minority question emanates from fear of domination of the minority groups by the dominant groups. It manifests at two levels. The first is at the federal level where the minorities complain against the major ethnic groups in the country. The second is at the state level where new dominant groups emerged on account of state creation. However, its manifestation at the federal level portends more danger to unity in Nigeria as the minorities and the major ethnic groups do not see themselves as partners in the progress and unity of the country. Rather, mutual distrust and suspicion between them is common; this impacts negatively on national unity.

The 1964-65 Tiv riots, for instance, which contributed in a way to the collapse of the First Republic had minority question undertone. Similarly, the April 22, 1990 Gideon Orkar's military coup had minority problem undertone. In his coup message broadcast on the national radio, Orkar announced the excision of Bauchi, Borno, Kano, Katsina and Sokoto States from Nigeria. The recent crisis in the Niger Delta area is also a manifestation of the minority problem with negative implications for the unity of Nigeria. Successive governments of Nigeria have attempted to deal with the minority problem through state creation, but the problem persists raising the question whether proliferation of states is really the solution to the minority question.

\section{PRO-UNITY MEASURES}

\section{A. Educational Policy}

Given the numerous challenges to the country's corporate existence, the need to put in place measures that make for unity has not been lost on successive governments of the polity. One of such measures is education. The concern here has been to use education as a tool to inculcate civil responsibilities and national spirit in the people of Nigeria. [5] This concern has given rise to a new national policy on education which, however, excludes History at the primary and junior secondary school levels. At the senior secondary school level where History is taught, the subject is regarded as an alternative to Government for the purpose of writing national examination like West African School Certificate (WAEC). But students at that level prefer Government to History apparently because more reading is required in the latter than in the former, to make good grades, and in a society that is increasingly losing the culture of reading, their preference would hardly be surprising since Government is less vast than History.

A society designs school curriculum consistent with its needs. During the colonial interlude, the colonial authorities designed school curriculum aimed at inculcating Western values in the beneficiaries. History was given a huge place, and the kind of history taught was consistent with the spirit of colonialism namely, the history of the British Empire, the greatness of Britain (Pax Britannica). [6] Little wonder that products of colonial schools were English in outlook and in mentality. The exclusion of History from school curriculum since the $1980 \mathrm{~s}$, is therefore a disservice to the country because products of the schools have no familiarity with their past. It should be noted that unity in any nation does not come from a vacuum but from a good knowledge of its past which only History provides. Therefore, a society that neglects its history does so to its own peril.

\section{B. National Youth Service Corps (NYSC)}

The NYSC was established by the Gowon administration in 1973 with a view to forging national unity in the country. The scheme affords young graduates of tertiary institutions the opportunity to render one year compulsory service in states other than their own. The programme is viewed as a veritable tool for promoting national unity. Inter-tribal marriages and other forms of social intercourse among members point to the usefulness of the scheme as a vehicle for national unity. However, the April 2011 post-elections violence in some parts of the country in which mayhem and killings were directed against innocent Corps members on national assignment gave some well meaning Nigerians cause to canvass the scrapping of the scheme. It is argued here that scrapping the scheme would not help national unity, but a review of the scheme which would ensure maximum security for members and reasonable sanctions on states that fail to ensure adequate security of Corps members in their domains is a better option. Accordingly, it would be in the interest of national unity for the NYSC scheme to be strengthened rather than scrapped.

\section{Physical Infrastructure}

Physical infrastructure like transport and communication are also essential ingredients of national unity not only in Nigeria but world-wide. Poor physical infrastructure impacts negatively on national unity. Good physical infrastructure aid 
regular movement of people, goods and services as well as the regular transmission of knowledge and information. As people interact using transport across geographical zones with ease, mutual distrust and suspicion among them melt away giving impetus to national unity. It is probably because of this that successive governments of the country endeavour to provide physical infrastructure. However, the good roads of the 1970 s and 1980s are now death trap due to official neglect thereby hampering inter-group relations among Nigerians. The railway system which flourished in the $1960 \mathrm{~s}$ and 1970s is today a shadow of its former self. The decay in infrastructure is taking place at a time Nigeria makes more foreign earnings from crude oil sale. There are, however, indications that the Goodluck Jonathan administration is making efforts to tackle the infrastructural decay frontally. This would no doubt give impetus to the ongoing efforts at attaining unity in the country.

\section{Mass Mobilisation}

This pro-unity strategy was extensively applied by the regime of Ibrahim Babangida under what it called Mass Mobilisation for Social and Economic Reconstruction (MAMSER). [7] MAMSER sought to reconstruct the damaged socio-political and economic values of Nigeria with emphasis on values that would promote national unity at the expense of primordial sentiments such as ethnicity, religion and so on. The programme though commendable was not properly packaged. It lacked the essential element apparently due to the disdain for history by the society. How do you reconstruct something you do not know how it existed before damage; this knowledge comes from history. Since those involved in the formulation of the concept had no knowledge of history, their product when put to test failed to achieve the desired result. Thus, Nigerians hardly felt the impact of the programme in terms of national unity. There can be no doubt that mass mobilisation rooted in the history of the people is an essential ingredient of national unity.

\section{UNITY-IN-DIVERSITY}

This too has been a measure in favour of national unity. It entails a country attempting to cultivate a sense of political unity among diverse ethnic groups, while at the same time upholding and maintaining social structures and cultural norms that make the groups disparate. This strategy has all along been applied by the country's leadership. Exponents of this strategy assume that the acceptance of common socio-political institutions is sufficient to make cohesive the disparate groups. India, Ghana and Kenya, for instance, have also been applying it. Nigeria is, however, having difficulty with it.

Take, for example, the policy of ethnic balancing which prescribes equitable representation of the constituent units in federal appointments. Though the policy is well intentioned in its goal of fostering ethnic harmony, it has nonetheless entrenched a culture of mediocrity across all levels of human behaviour in Nigeria and perhaps other parts of Africa. This is so because qualification and professionalism are sacrificed for political expediency in political and civil service appointments. However, if the principle of ethnic-balancing is properly applied, it could be a veritable instrument of ethnic harmony and national unity.

\section{A. Lessons from History}

Nigerians are today paying the price of being ignorant of the basic knowledge of their history. It is for this reason that some are questioning the basis of the corporate existence of the Nigerian groups. Arising from this is the call for Nigeria to be split into two or more fragments. This call is a desperate one and arises from lack of knowledge of the country's past.

A study of the country's traditional political value, for instance, could provide useful lessons in the collective efforts at attaining a purposeful and patriotic political leadership in the country. In the pre-colonial Nigeria's political culture, leaders must be people of integrity and well versed in the culture of the people and were elected or appointed in accordance with the laws and customs of the people. [8] This way, those who emerged as leaders were accepted by all and were obligated to work for the good of the polity including unity. Those found wanting was severely sanctioned. Sanctions ranged from forfeiture of right to office to death.

Nigeria's contemporary experience shows a complete break with the cherished traditional values of political culture. All too often leaders rig themselves into power in total disregard of the laws of the land. Moreover, most of such leaders lack the basic ingredients of leadership namely, integrity, knowledge of the culture of the people, selflessness and patriotism. Such leaders perpetuate themselves in power through the policy of divide and rule. To these leaders, unifying the people is detrimental to their selfish political interests. This partly explains the manipulation of ethnicity and religion by some of the leaders for selfish political interest. But if such leaders were to have familiarity with the history of the people, their attitude would be different.

There is also a lesson to learn from the country's traditional political culture in the area of conflict management. In all communities, conflict management was guided by the necessity to keep the community together. This involved the adoption of the concepts of compensation, restitution, restoration and reconciliation. Where payment of compensation was necessary, it was done to ensure proper coverage of loss or damage suffered during conflict. The rationale behind this was to prevent injustice and forestall further conflict within the communities. Rarely did perpetrators go unpunished. The reality in contemporary Nigeria is that perpetrators of conflict which cause disaffection and disharmony within the policy are hardly punished. Also, the victims of conflict are left to moan their losses without compensation. This official attitude amounts to sweeping burning issues with the potential of tearing the polity apart under the carpet. Little wonder that conflicts, especially ethno-religious conflicts keep recurring with dangerous implications for the country's unity. It is argued that a judicial system based on the history of the people could minimise such conflicts.

The pre-colonial history of Nigeria tells us that the different ethnic nationalities we find in Nigeria today are not as far apart as we are made to believe. The different ethnic groups did not come to know themselves during the colonial era as is often said. They knew themselves before the advent 
of white rule as evident in the wide range of socio-economic ties between them. These ties are discernible from the traditions of the Nigerian people. For example, the Oduduwa legend established common ancestry between the Yoruba and Edo. The Bayyajida legend established links between the Yoruba and Nupe through the Bokwoi and Banza networks. The Igbo, on their own part, had commercial and social contacts with the Ijo, the Efik, the Ejagham, the Edo and the Igala. [9]

A further evidence of unity in the Nigerian history comes from historical linguistics which has proved beyond all reasonable doubt the relationships between the various ethnic groups in the country. According to this evidence, the languages spoken in Nigeria today are said to belong to three major language families namely, Nilo-Saharan represented by Kanuri, Afro-Asiatic represented by Shuwa Arab, and the Chadie branch of which Hausa has the greatest number of speakers and the Niger-Congo which has the remaining languages in Nigeria. Seventy-five percent of the languages in Nigeria belong to the Benue-Congo, a sub-group of the Niger-Congo language family. This conclusion was arrived at by examining the similarities between languages. The languages include Edo, Yoruba, Igbo, Efik, Ibibio, Ejagham, Tiv, Itsekiri, Igala, Ijo, Nupe, Idoma, Kambari, to mention a few. [10] It is safe to say that if most of the languages spoken in Nigeria today have a common origin, then the speakers of such languages have a common ancestry. It is to be noted that knowledge of the affinity among Bigerian languages which comes only from historical linguistics has the potential of engendering a sense of unity among Nigerians.

\section{CONCLUSION}

Nigeria has been grappling with the problem of unity since independence. Since the civil war, crisis has been a recurring decimal in the country. Successive governments of the country, in a bid to keep centrifugal forces under check, have put in place unity-promoting measures, which, however, have not yielded the expected result. Matters are not helped by the relegation of history to the background in the country's school's system. This is why we are making mistakes on a daily basis. Nigeria ceded the Bakassi Peninsula to Cameroun largely because of the country's disdain for history. The team assembled to defend Nigeria's interests in the area did not include any historian who could have validated the country's claim to the oil-rich area from the perspective of history. Similarly, at the national level, panels have often been constituted to enquire about crises in the country. In all cases, historians have never been members of such panels. Thus, reports submitted by such panels lack historical background to such crises. Little wonder that crises recur. There are more things that make for unity than those that keep Nigerians apart. Only history can expose those binding elements.

\section{REFERENCES}

[1] E. E. Osaghae, Nigeria Since Independence: Cripple Giant, $1^{\text {st }}$ ed., London: C. Hurst \& Co. Publishers, 1998, pp. 4.

[2] C. Ake, Democracy and Development in Africa, $1^{\text {st }}$ ed., Washington, DC: Brooklyn Institution, 1996, pp. 42.

[3] D. O. Alabi, "Ethno-religious conflicts in Kaduna State: Origins, development and management," in Studies on Kaduna State, $1^{\text {st }}$ ed., C. N. Ubah et.al Eds. Kaduna: Pyla-Mak Services Ltd., 2008, pp. 373-385.

[4] O. Akinwumi, Before We Set the House Ablaze: Let us Consult Our Oracle History, $1^{\text {st }}$ ed., Keffi: Nasarawa State University Press, 2009, pp. 25.

[5] Centre for Democratic Development Research and Training, Corruption in Nigeria: Selected Writings of Yusufu Bala Usman, $1^{\text {st }}$ ed., Kaduna: M.O. Press \& Publishers, 2008, pp. 95-110.

[6] O. E. Tangban, The Ejagham Under colonial Rule: A Study of Socio-Economic and Political Changes, 1891-1961, $1^{\text {st }}$ ed., Kaduna: Precious Publishers, 2008, pp. 224.

[7] A. E. Osewe, "The role of history in rebranding Nigeria," Arts and social Science Research, vol. 5, pp. 107-109, Sept. 2010.

[8] E. J. Alagoa, "Values in Nigeria's traditional political culture," paper presented at a National Seminar on Issues in Nigeria's Political Culture: Values and Leadership, Kaduna, Dec., 1989, pp. 5-10.

[9] O. Ikime, "History for the development of Nigeria", in History, the Historian and the Nation, $1^{\text {st }}$ ed. O. Ikime, Ibadan: Longman, 1988, pp. 51-52.

[10] K. Williamson, "Indigenous languages of the Niger-Benue confluence region: Their classification and implications for pre-history," Inaugural lecture, University of Port-Harcourt, 1980.

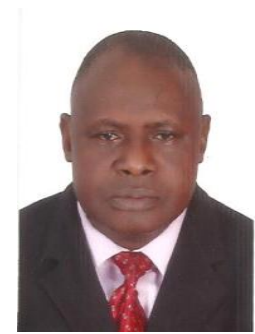

Ojong Echum Tangban was born in Bendeghe Ekiem, Cross River State, Nigeria, on January 1, 1953. His degrees include: B. A degree (Second Class Honours, Upper Division) in History/Archaeology, University of Nigeria, Nsukka, Enugu State, Nigeria, 1977: 1) Master of Philosophy (M.Phil) in History, University of Calabar, Calabar, Cross River State, Nigeria, 1982; 2)Doctor of Philosophy (Ph.D) in History, Ahmadu Bello University, Zaria, Kaduna State, Nigeria, 1996. Author's major field of study is African history with bias toward social and economic issues. He has to his credit several publications notably among them are the following: 1) The Ejagham Under Colonial Rule: A Study of socio-Economic and Political Changes, 1891-1961, Kaduna: Precious Publishers, 1988. 2) Co-editor of Nigeria in Global Peace Support Operations, Kaduna: Pyla-Mak Services Ltd., 2013. 3) Co-editor of Perspectives in African Historical Studies, Kaduna: NDA Press, 2013.

Professor Tangban is a member of the Historical Society of Nigeria (HSN) and Institute of Mentoring and Career Coaching Nigeria. His awards include Fellow Professional Mentor and Coach (FPMC), and ICON of Mentorship in Nigeria (ICMN). 